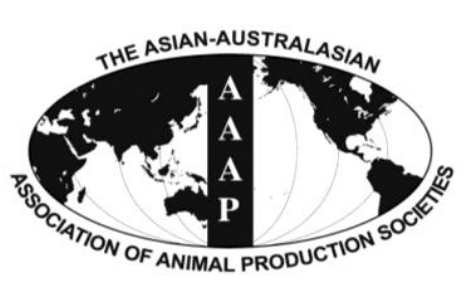

Open Access

Asian Australas. J. Anim. Sci.

Vol. 27, No. 5 : 667-673 May 2014

http://dx.doi.org/10.5713/ajas.2013.13604

www.ajas.info

pISSN 1011-2367 elSSN 1976-5517

\title{
Effects of Forage Sources on Rumen Fermentation Characteristics, Performance, and Microbial Protein Synthesis in Midlactation Cows
}

\author{
Jun Xua, Yujie Hou', Hongbo Yang, Renhuang Shi, Caixia Wu, Yongjiu Huo, and Guoqi Zhao* \\ College of Animal Science and Technology, Yangzhou University, Yangzhou, 225009, China
}

\begin{abstract}
Eight multiparous Holstein cows (632 $\pm 12 \mathrm{~kg} \mathrm{BW} ; 135 \pm 16$ DIM) were used in a replicated $4 \times 4$ Latin square design to evaluate the effects of forage sources on rumen fermentation characteristics, performance, and microbial protein (MCP) synthesis. The forage portion of the diets contained alfalfa hay $(\mathrm{AH})$, oat hay $(\mathrm{OH})$, Leymus chinensis (LC), or rice straw (RS) as the primary source of fiber. Diets were isonitrogenous and isocaloric, and cows were fed four corn silages based total mixed rations with equivalent nonfiber carbohydrate (NFC) and forage neutral detergent fiber (NDF). Dry matter intake was not affected by the source of dietary forages, ranging from 18.83 to $19.20 \mathrm{~kg} / \mathrm{d}$, consequently, milk yield was similar among diets. Because of the numerical differences in milk fat and milk protein concentrations, 4\% FCM and ECM yields were unchanged ( $\mathrm{p}>0.05)$. Mean rumen $\mathrm{pH}, \mathrm{NH}_{3}-\mathrm{N}$ content, and concentrations of volatile fatty acids in the rumen fluid were not affected by the treatments $(\mathrm{p}>0.05)$. Dietary treatments did not affect the total tract apparent digestibility of dry matter, organic matter, and crude protein ( $p>0.05)$; however, digestibility of NDF and acid detergent fiber in RS diet was higher compared with $\mathrm{AH}, \mathrm{OH}$, and $\mathrm{LC}$ diets $(\mathrm{p}<0.05)$. Total purine derivative excretion was higher in cows fed $\mathrm{AH}, \mathrm{OH}$, and LC diets compared with those fed RS diet $(\mathrm{p}<0.05)$, consequently, estimated MCP synthesis was $124.35 \mathrm{~g} / \mathrm{d}$ higher in cows fed AH diet compared with those fed RS diet $(\mathrm{p}<0.05)$. The results indicated that cows fed AH, OH, LC, and RS diets with an equivalent forage NDF and NFC have no unfavourable effect on the ruminal fermentation and productive parameters. (Key Words: Forage, Rumen Fermentation, Microbial Protein, Cows)
\end{abstract}

\section{INTRODUCTION}

Adequate dietary fiber is very important for dairy cow to maintain rumen health and microbial protein (MCP) synthesis by sustaining a stable environment in the rumen. Forage usually makes up half or more of the diet of a lactating dairy cow, affecting the dry matter intake (DMI) and thereby affecting the energy and carbohydrate intake (Kendall et al., 2009). However, high-quality forages such as alfalfa hay $(\mathrm{AH})$ are especially in short supply with the gap between supply and demand increasing by $10 \%$ annually (Zhu et al., 2013). In China, the primary sources of fiber in ruminant diets are corn silage and grasses (Leymus

\footnotetext{
* Corresponding Author: Guoqi Zhao. Tel: +86-514-8799-7195, Fax: +86-514-8735-0440, E-mail: jszhaoguoqi@sohu.com

${ }^{a}$ These authors contributed equally to this work and should be considered co-first authors.

Submitted Sept. 27, 2013; Revised Dec. 31, 2013; Accepted Jan. 12, 2014
}

chinensis) and oat hay being the most prevalent. At the same time, rice straw (RS) is also an important roughage resource particularly during summer months for dairy cows (Su et al., 2012), and it is being added to rations on many Chinese dairy farms.

The contents of crude protein (CP), nonfiber carbohydrate (NFC), neutral detergent fiber (NDF), and digestibility of NDF are different among these forages. $\mathrm{AH}$ is generally regarded as one of the best forages for dairy cows because of its perceived high contents of CP and NFC compared with the grasses and RS; however, the price of $\mathrm{AH}$ in China has risen sharply and $230 \times 10^{6} \mathrm{~kg}$ of $\mathrm{AH}$ has been imported from United States (Wang, 2011). However, the annual yield of RS is about 188 million tons in China (Guo et al., 2002), and oat hay (OH) and Leymus chinensis (LC) have been extensively included in dairy cow rations (Yang et al., 2009).

Previous studies have generally reported that feeding 
alfalfa hay increased DMI, MCP, and performance of goats (Cantalapiedra-Hijar et al., 2009) and lactating dairy cows (Vanhatalo et al., 2009; Holt et al., 2013; Zhu et al., 2013). In contrast, several studies have shown that forage sources have no unfavourable effect on the productive parameters (Gencoglu et al., 2007) and alfalfa hay can be replaced by grass hay or straw on corn silage based diets to lactating dairy cows (Eastridge et al., 2009). The objectives of this experiment were to determine the effects of forage sources on rumen fermentation characteristics, lactating performance, and MCP synthesis in midlactation dairy cows fed equivalent concentrations of forage NDF (FNDF) and NFC diets.

\section{MATERIALS AND METHODS}

\section{Animals, diets and experimental design}

Eight multiparous Chinese Holstein cows $(632 \pm 12 \mathrm{~kg}$ BW; $135 \pm 16$ DIM) were used in a replicated $4 \times 4$ Latin square design experiment. Each period consisted of $21 \mathrm{~d}$, with $14 \mathrm{~d}$ for dietary adaptation followed by $7 \mathrm{~d}$ for sampling. The four diets were formulated to consist of about $185 \mathrm{~g}$ FNDF/kg dietary dry matter (DM) from corn silage and beet pellets, and $65 \mathrm{~g} \mathrm{FNDF/kg} \mathrm{dietary} \mathrm{DM} \mathrm{from}$ $\mathrm{AH}, \mathrm{OH}, \mathrm{LC}$, or RS, equivalent to $250 \mathrm{~g} \mathrm{FNDF} / \mathrm{kg}$ dietary $\mathrm{DM}$ in the diets. All the diets were isonitrogenous and isocaloric, and the level of NDF and NFC also were similar. Diets were mixed once daily and fed ad libitum three times daily at 06:30, 14:30, and 22:30 h and adjusted feed offered for $0.10 \mathrm{~kg}$ refusal. All of the cows were housed in a tiestall barn and had free access to drinking water throughout the experiment. The ingredients and chemical composition of the diets are shown in Table 1.

\section{Sampling collection and measurements}

Feed intake was recorded daily throughout the experiment, but only measurements on d 15 to 19 are reported in the current paper. The concentrates and forages were sampled each week to determine the DM content. Samples of the total mixed ration (TMR) and orts were collected for 3 consecutive days on d 15, 16, and 17 of each period. Grab fecal samples (250 g per sampling) were collected from the rectum at $06: 30,14: 30$, and 22:30 h on d 17,18 , and 19 of each period. Samples were then pooled by treatment, period, and cow, and then the subsamples were used for chemical analysis. Samples were analyzed for DM and then dried at $65^{\circ} \mathrm{C}$ in an oven for $48 \mathrm{~h}$. Dried feed samples were ground through a 1-mm screen in a Wiley Mill and stored at $-20^{\circ} \mathrm{C}$ until analyzed for $\mathrm{CP}$, ash, and ether extract (EE) according to the procedures of the Association of Official Analytical Chemists (AOAC, 1990). The NDF and acid detergent fiber (ADF) were analyzed by the method of Van Soest et al. (1991). NFC was calculated
Table 1. Ingredient composition and chemical analysis of experimental TMR diets fed to lactating dairy cows

\begin{tabular}{lcccc}
\hline \multirow{2}{*}{ Item } & \multicolumn{4}{c}{ Source of forage fiber in the diet } \\
\cline { 2 - 5 } & $\begin{array}{c}\text { Alfalfa } \\
\text { hay }\end{array}$ & $\begin{array}{c}\text { Oat } \\
\text { hay }\end{array}$ & $\begin{array}{c}\text { Leymus } \\
\text { chinensis }\end{array}$ & Rice \\
straw \\
\hline TMR ingredient (\% of diet DM) & & & \\
Alfalfa hay & 13.00 & 0.00 & 0.00 & 0.00 \\
Oat hay & 0.00 & 10.50 & 0.00 & 0.00 \\
Leymus chinensis & 0.00 & 0.00 & 10.00 & 0.00 \\
Rice straw & 0.00 & 0.00 & 0.00 & 9.50 \\
Corn silage & 32.00 & 32.00 & 32.00 & 32.00 \\
Beet pellet & 3.00 & 3.00 & 3.00 & 3.00 \\
Whole cottonseed & 2.00 & 4.50 & 5.00 & 5.50 \\
Corn & 21.00 & 21.00 & 21.00 & 21.00 \\
Soybean meal & 7.50 & 10.50 & 11.50 & 11.50 \\
Cottonseed meal & 2.50 & 2.50 & 2.50 & 2.50 \\
DDGS & 10.00 & 10.00 & 10.00 & 10.00 \\
Soybean hulls & 5.00 & 2.00 & 1.00 & 1.00 \\
Calcium & 1.28 & 1.28 & 1.28 & 1.28 \\
$\quad$ hydrophosphate & & & & \\
Salt & 0.62 & 0.62 & 0.62 & 0.62 \\
Sodium bicarbonate & 1.20 & 1.00 & 1.00 & 1.00 \\
Premix ${ }^{1}$ & 0.60 & 0.60 & 0.60 & 0.60 \\
Limestone & 0.30 & 0.50 & 0.50 & 0.50 \\
Composition $(\%$ DM) & & & & \\
CP & 16.07 & 16.04 & 16.22 & 16.09 \\
EE & 3.90 & 4.15 & 4.33 & 4.25 \\
NDF & 35.87 & 35.63 & 35.31 & 35.67 \\
ADF & 21.09 & 21.04 & 21.07 & 22.84 \\
Ash & 8.63 & 8.45 & 8.14 & 8.63 \\
NFC & 35.44 & 35.63 & 35.50 & 35.29 \\
NE (Mcal/kg of DM) & 1.61 & 1.62 & 1.63 & 1.61 \\
FNDF & 24.98 & 24.99 & 24.91 & 25.04 \\
Ca & 0.69 & 0.69 & 0.69 & 0.67 \\
P & 0.38 & 0.40 & 0.41 & 0.39 \\
\hline
\end{tabular}

TMR, total mixed ration; DDGS, distillers dried grains with solubles. CP, crude protein; EE, ether extract; NDF, neutral detergent fiber; ADF, acid detergent fiber; NFC, nonfiber carbohydrate; NE, net energy for lactation; FNDF, forage neutral detergent fiber.

${ }^{1}$ Formulated to provide (per kilogram of DM) 400,000 IU of vitamin A, $80,000 \mathrm{IU}$ vitamin D, 2,000 IU of vitamin E, 5,000 mg Zn, $40 \mathrm{mg} \mathrm{Se}$, 2,000 mg Mn, 2,000 mg Fe, $20 \mathrm{mg} \mathrm{Co,} \mathrm{1,200} \mathrm{mg} \mathrm{Cu,} 50 \mathrm{mg} \mathrm{I}$.

${ }^{2}$ Caculated as $100-(\% \mathrm{NDF}+\% \mathrm{CP}+\% \mathrm{EE}+\% \mathrm{Ash})$.

as $100-(\mathrm{CP}+\mathrm{NDF}+\mathrm{EE}+\mathrm{Ash})$. Calcium (Ca) and phosphorus (P) were measured by inductively coupled plasma emission spectroscopy (AOAC, 1990). Total tract apparent digestibility of DM, organic matter (OM), CP, NDF, and ADF was estimated using acid insoluble ash as an intrinsic marker.

Milk production was recorded daily during the $7 \mathrm{~d}$ data collection period. Cows were milked at 07:00, 15:00, and 23:00 h daily, on d 17, 18, and 19 of each experimental period, $50 \mathrm{~mL}$ milk samples were collected in a proportion of 4:3:3 from morning to evening milkings into plastic vials. 
Milk samples were then pooled daily based on milk yield and stored at $4{ }^{\circ} \mathrm{C}$ for later analysis of the $\mathrm{CP}$, fat, and lactose using a near infrared analyzer (Foss System 4000, Foss Electric, Hillerød, Denmark) according to AOAC (1990).

On d 19 and 20 of each period, ruminal fluid samples were aspirated with an esophageal tube and a pump approximately $4 \mathrm{~h}$ after the morning feeding. After discarding the initial draw of $150 \mathrm{~mL}$ to minimize the contamination of saliva, the $\mathrm{pH}$ of the fluid was immediately measured using a Model 265A portable $\mathrm{pH}$ meter. Five milliliters of fluid were mixed with chilled $25 \%$ meta-phosphoric acid $\left(\mathrm{H}_{2} \mathrm{PO}_{4}\right)$ for volatile fatty acid (VFA) analysis, $2 \mathrm{~mL}$ was mixed with 0.5 M HCL for ammonia-N $\left(\mathrm{NH}_{3}-\mathrm{N}\right)$ determination. Ruminal fluid samples were centrifuged at $15,000 \times g$ for $20 \mathrm{~min}$ at $4{ }^{\circ} \mathrm{C}$. $\mathrm{NH}_{3}-\mathrm{N}$ content of ruminal samples were determined by Chaney and Marbach (1962) modified to use a microtiter plate reader. Rumen VFA were separated and quantified by HPLC (Samuel et al., 1997).

Urine samples (about $100 \mathrm{~mL}$ were collected by spot sampling at approximately 6 and $12 \mathrm{~h}$ after feeding on $\mathrm{d} 17$, 18 , and 19 of each period. The daily urine samples were acidified by diluting $20 \mathrm{~mL}$ of urine with $80 \mathrm{~mL}$ of $0.036 \mathrm{M}$ $\mathrm{H}_{2} \mathrm{SO}_{4}$ and stored at $-20^{\circ} \mathrm{C}$ until analyzed. Urine samples were later thawed, composited to one sample per period per cow, and analyzed for allantoin, uric acid, and creatinine. Concentrations of allantoin and uric acid in urine were determined using the method described by Chen and Gomes (1995). Creatinine concentration in urine was determined using a commercial kit (Sigma no. 555; Sigma Chemical Co., St. Louis, MO, USA). The purine derivatives allantoin and uric acid were used as an estimate of MCP synthesis to the duodenum, and daily urine volume and excretion of purine derivatives (PD; allantoin plus uric acid) were estimated from mean urinary concentrations assuming a creatinine excretion rate of $29 \mathrm{mg} / \mathrm{kg}$ of BW (Valadares et al., 1999).

On d 21 of each period, blood samples $(5 \mathrm{~mL})$ were collected $4 \mathrm{~h}$ after the morning feeding from each cow via jugular venipuncture into heparinized tubes. Plasma was prepared immediately after collection by centrifugation of blood at $3,000 \times g$ for $15 \mathrm{~min}$ and then stored at $-20^{\circ} \mathrm{C}$ until further analysis. Plasma urea-N (PUN) and glucose were determined using an Olympus AU 640 Chemistry Analyzer (Olympus, Tokyo, Japan).

\section{Statistical analysis}

The data were analyzed as a replicated $4 \times 4$ Latin square using the PROC MIXED procedure of SAS (SAS Institute, 2000) using the following model: $\mathrm{Y}_{\mathrm{ijkl}}=$ $\mu+\mathrm{S}_{\mathrm{i}}+\mathrm{P}_{\mathrm{j}(\mathrm{i})}+\mathrm{C}_{\mathrm{k}(\mathrm{i})}+\mathrm{T}_{1}+\varepsilon_{\mathrm{ijkl}}$, where $\mathrm{Y}_{\mathrm{ijkl}}=$ represents of observation from animals, $\mu=$ overall mean, $S_{i}=$ fixed effect of square $\mathrm{i}, \mathrm{P}_{\mathrm{j}(\mathrm{i})}=$ fixed effect of period $\mathrm{j}$ (within square $\mathrm{i}$ ), $\mathrm{C}_{\mathrm{k}(\mathrm{i})}=$ random effect of cow $\mathrm{k}$ (within square $\mathrm{i}$ ), $\mathrm{T}_{1}$ = fixed effect of treatment 1 , and $\varepsilon_{\mathrm{ijkl}}=$ random residual error. All reported values are least squares means, which were separated using the PDIFF option in SAS. A statistically significant difference was defined at $\mathrm{p}<0.05$.

\section{RESULTS}

The ingredient composition and chemical analysis of experimental TMR are presented in Table 1. Dietary NDF, FNDF, and NFC contents were (mean \pm SE) 35.62 \pm 0.23 , $24.98 \pm 0.05$, and $35.47 \pm 0.14 \%$ (DM basis) respectively, the four diets were also isonitrogenous and isocaloric. The ADF content of the RS diet was numerically higher than that of $\mathrm{AH}, \mathrm{OH}$, and LC diets (Table 1).

Daily DMI was similar ( $>>0.05)$ among the treatments, with an average of $19.00 \mathrm{~kg} / \mathrm{d}$. Milk yield was higher for AH diet than for RS diet but it was not significant $(\mathrm{p}>0.05)$. Milk fat, milk protein, and lactose contents were similar among the four diets $(p>0.05)$. Because of the numerical differences in milk yield, milk fat, and milk protein concentrations, the $4 \%$ fat-collected milk (FCM) and energy-corrected milk (ECM) output were similar among the diets. Cows fed RS diet had a greater concentration of PUN than those fed $\mathrm{AH}, \mathrm{OH}$, and LC diets, but not differing from each other $(\mathrm{p}>0.05)$ (Table 2$)$.

Concentrations of mean ruminal $\mathrm{pH}, \mathrm{NH}_{3}-\mathrm{N}$, total VFA, and individual acids were similar among the four diets (Table 3). Cows fed RS diet had a lower proportion of acetate and higher proportion of propionate, but it was not significant $(\mathrm{p}>0.05)$. Total tract digestibility of DM, OM, and $\mathrm{CP}$ was not affected by dietary sources of forage fiber (Table 4), but total tract NDF and ADF digestibilities were higher in cows fed RS diet compared with those fed AH diet $(\mathrm{p}<0.05)$. Urinary purine derivative excretion and MCP production estimates are shown in Table 5. Daily excretion of the purine derivative uric acid was not affected by any of the dietary treatments $(p>0.05)$, but excretion of allantoin was higher for cows fed AH compared with those fed RS $(\mathrm{p}<0.05)$, and intermediate in cows fed $\mathrm{OH}$ and LC. Total excretion of purine derivatives were higher for $\mathrm{AH}, \mathrm{OH}$, and LC diets than for RS diet, and consequently, the calculated intestinal flow of MCP decreased from 1,823 to $1,699 \mathrm{~g} / \mathrm{d}$ when cows were fed AH compared with those fed RS.

\section{DISCUSSION}

It is well accepted in the literature that the main factor restricting voluntary DMI by lactating cows is dietary NDF content (Adin et al., 2009), and when forages are the main or sole source of NDF, the contents of DMI and NDF are 
Table 2. Effects of alfalfa hay, oat hay, Leymus chinensis, and rice straw as dietary forage sources on the DMI, milk production, and plasma metabolites of dariy cows

\begin{tabular}{lcccccc}
\hline \multirow{2}{*}{ Item } & \multicolumn{3}{c}{ Source of forage fiber in the diet } & \multirow{2}{*}{ SEM } & \multirow{2}{*}{ p-value } \\
\cline { 2 - 4 } & Alfalfa hay & Oat hay & Leymus chinensis & Rice straw & & 0.12 \\
DMI (kg/d) & 19.20 & 18.95 & 18.83 & 18.98 & 0.25 \\
Milk yield (kg/d) & 24.77 & 24.34 & 24.48 & 23.95 & 0.58 & 0.80 \\
Fat (\%) & 3.44 & 3.42 & 3.40 & 3.48 & 0.03 & 0.24 \\
Protein (\%) & 3.10 & 3.03 & 2.98 & 3.01 & 0.45 & 0.42 \\
Lactose (\%) & 4.62 & 4.57 & 4.66 & 4.60 & 0.05 & 0.69 \\
$4 \%$ FCM $^{1}(\mathrm{~kg} / \mathrm{d})$ & 21.76 & 21.32 & 21.34 & 21.14 & 0.56 & 0.88 \\
ECM $^{2}(\mathrm{~kg} / \mathrm{d})$ & 23.65 & 23.08 & 23.03 & 22.81 & 0.55 & 0.74 \\
Plasma glucose (mmol/L) & 3.52 & 3.54 & 3.56 & 3.59 & 0.04 & 0.56 \\
Plasma urea-N (mmol/L) & 5.30 & 5.31 & 5.34 & 5.45 & 0.07 & 0.12 \\
\hline DMI,
\end{tabular}

DMI, dry matter intake; SEM, standard error of the mean.

${ }^{1} \mathrm{FCM}=$ Fat-collected milk, calculated as $(0.4 \times \mathrm{kg}$ of milk $)+(15 \times \mathrm{kg}$ of milk fat $)$.

${ }^{2} \mathrm{ECM}=$ Energy-corrected milk, calculated as $(0.327 \times \mathrm{kg}$ of milk $)+(12.95 \times \mathrm{kg}$ of milk fat $)+(7.2 \times \mathrm{kg}$ of milk protein $)$.

Table 3. Effects of alfalfa hay, oat hay, Leymus chinensis, and rice straw as dietary forage sources on ruminal fermentation

\begin{tabular}{|c|c|c|c|c|c|c|}
\hline \multirow{2}{*}{ Item } & \multicolumn{4}{|c|}{ Source of forage fiber in the diet } & \multirow{2}{*}{ SEM } & \multirow{2}{*}{ p-value } \\
\hline & Alfalfa hay & Oat hay & Leymus chinensis & Rice straw & & \\
\hline$\overline{\text { Rumen pH }}$ & 6.35 & 6.40 & 6.42 & 6.46 & 0.04 & 0.37 \\
\hline $\mathrm{NH}_{3}-\mathrm{N}(\mathrm{mg} / \mathrm{dL})$ & 10.95 & 10.44 & 10.58 & 11.29 & 0.30 & 0.27 \\
\hline Total VFA (mM) & 114.03 & 116.14 & 116.28 & 111.74 & 2.32 & 0.27 \\
\hline Acetate $(\mathrm{mol} / 100 \mathrm{~mol})$ & 65.96 & 65.53 & 65.26 & 64.99 & 0.86 & 0.87 \\
\hline Propionate $(\mathrm{mol} / 100 \mathrm{~mol})$ & 19.27 & 19.95 & 19.74 & 20.12 & 0.46 & 0.62 \\
\hline Isobutyrate $(\mathrm{mol} / 100 \mathrm{~mol})$ & 1.04 & 1.05 & 1.03 & 1.04 & 0.03 & 0.99 \\
\hline Butyrate (mol/100 mol) & 11.08 & 11.50 & 11.35 & 11.46 & 0.42 & 0.89 \\
\hline Isovalerate $(\mathrm{mol} / 100 \mathrm{~mol})$ & 1.50 & 1.54 & 1.49 & 1.48 & 0.03 & 0.60 \\
\hline Valerate $(\mathrm{mol} / 100 \mathrm{~mol})$ & 1.16 & 1.18 & 1.13 & 1.16 & 0.03 & 0.78 \\
\hline Acetate:Propionate & 3.44 & 3.25 & 3.31 & 3.26 & 0.12 & 0.66 \\
\hline
\end{tabular}

VFA, volatile fatty acid.

correlated negatively with each other (Ranathunga et al., 2010). Rode et al. (1985) reported that DMI was also affected by long forage but not by chopped or ground forage in diets of dairy cows. The DMI (averaged 19.00 $\mathrm{kg} / \mathrm{d}$ ) did not differ among the four diets. In our study, the forages used were chopped at 3 to $5 \mathrm{~cm}$ and concentrations of NDF were similar among the diets, which can explain the present results. In addition, there was no difference in milk yield for cows fed diets containing $\mathrm{AH}, \mathrm{OH}, \mathrm{LC}$, and RS as the main source of forage fiber. In some previous studies, the increased DMI was the primary reason for increased milk production (Yan et al., 2011), and the lack of difference in DMI may be due to the similar milk yield among the treatments (averaging $24.39 \mathrm{~kg} / \mathrm{d}$ ). Gencoglu et al. (2007) observed that DMI, 4\% FCM, and milk yield were similar in cows fed wheat straw compared to chopped alfalfa hay in the diets. Eastridge et al. (2009) reported similar milk fat and milk protein contents in cows fed $\mathrm{AH}$, grass hay, wheat straw, and whole cottonseed in corn silage based diets. In contrast, Zhu et al. (2013) discovered no

Table 4. Effects of alfalfa hay, oat hay, Leymus chinensis, and rice straw as dietary forage sources on apparent total tract digestibility of nutrients

\begin{tabular}{|c|c|c|c|c|c|c|}
\hline \multirow{2}{*}{ Item } & \multicolumn{4}{|c|}{ Source of forage fiber in the diet } & \multirow{2}{*}{ SEM } & \multirow{2}{*}{ p-value } \\
\hline & Alfalfa & Oat hay & Leymus chinensis & Rice straw & & \\
\hline$\overline{\mathrm{DM}}$ & 65.01 & 64.39 & 64.23 & 66.13 & 0.57 & 0.19 \\
\hline $\mathrm{OM}$ & 64.94 & 64.52 & 64.10 & 64.32 & 0.30 & 0.32 \\
\hline $\mathrm{NDF}$ & $50.47^{\mathrm{b}}$ & $48.11^{\mathrm{c}}$ & $48.32^{\mathrm{c}}$ & $52.75^{\mathrm{a}}$ & 0.52 & $<0.01$ \\
\hline $\mathrm{ADF}$ & $43.68^{\mathrm{b}}$ & $43.96^{\mathrm{ab}}$ & $45.13^{\mathrm{ab}}$ & $45.66^{\mathrm{a}}$ & 0.56 & 0.02 \\
\hline $\mathrm{CP}$ & 63.54 & 62.67 & 62.92 & 63.31 & 0.90 & 0.90 \\
\hline
\end{tabular}

SEM, standard error of the mean; DM, dry matter; OM, organic matter; NDF, neutral detergent fiber; ADF, acid detergent fiber; CP, crude protein.

${ }^{a, b, c}$ Means within a row with different superscripts differ $(\mathrm{p}<0.05)$. 
Table 5. Urine output, urinary purine derivative excretion, and microbial $\mathrm{N}$ supply in dairy cows fed diets containing alfalfa hay, oat hay, Leymus chinensis, and rice straw as dietary forage sources

\begin{tabular}{lcccccc}
\hline & \multicolumn{3}{c}{ Source of forage fiber in the diet } & SEM & p-value \\
\cline { 2 - 5 } Item & Alfalfa & Oat hay & $\begin{array}{c}\text { Leymus } \\
\text { chinensis }\end{array}$ & Rice straw & & \\
\hline Urine output (kg/d) & 29.20 & 29.85 & 30.33 & 31.34 & 0.48 & 0.08 \\
Allantoin (mmol/d) & $343.01^{\mathrm{a}}$ & $335.43^{\mathrm{a}}$ & $333.81^{\mathrm{a}}$ & $320.76^{\mathrm{b}}$ & 3.08 & 0.01 \\
Uric acid (mmol/d) & 46.58 & 46.03 & 44.98 & 45.40 & 1.46 & 0.87 \\
Total purine derivatives (mmol/d) & $389.59^{\mathrm{a}}$ & $384.11^{\mathrm{a}}$ & $381.48^{\mathrm{a}}$ & $366.16^{\mathrm{b}}$ & 3.46 & 0.01 \\
MCP $(\mathrm{g} / \mathrm{d})$ & $1,823.65^{\mathrm{a}}$ & $1,791.10^{\mathrm{a}}$ & $1,781.21^{\mathrm{a}}$ & $1,699.30^{\mathrm{b}}$ & 17.62 & 0.01 \\
\hline
\end{tabular}

MCP, microbial protein.

${ }^{a, b}$ Means within a row with different superscripts differ $(\mathrm{p}<0.05)$.

differences in milk fat contents in cows fed corn silage, LC, and $\mathrm{AH}$ diets; however, milk protein was the highest in cows fed AH compared with those fed corn silage or LC. Some studies reported that the raised intake of FNDF increased milk fat content and decreased milk protein content (Kononoff and Heinrichs, 2003). Because the CP, FNDF, and NFC concentrations were similar in the current study, proportions and yields of milk fat, milk protein, $4 \%$ FCM, and ECM were not affected by the treatments.

The provision of forage fiber in the diet is an important factor for maintaining ruminal health, dietary NFC content, and fermentability. These factors are important in determining rumen $\mathrm{pH}$, but forage physical form (physically effective NDF) exerts the dominant control over pH (Haddad and Grant, 2000), and the NRC recommends at least $75 \% \mathrm{NDF}$ in the dietary DM should be supplied by forages. In our study, the diets were formulated to have similar concentrations of FNDF and NFC, and this might explain why the ruminal $\mathrm{pH}$ and total VFA concentrations were unaffected by the dietary treatments; in addition, the lack of the influence of diet on VFA may also mean that rumen $\mathrm{pH}$ is not likely to be affected as well. These results are consistent with Eastridge et al. (2009) who reported that the rumen fermentation characteristics were not affected by the forage sources. The lack of differences in proportions of acetate and propionate may be due to the similar concentrations of NDF and starch content (Owens et al., 2009). In agreement with the literature reported by Eastridge et al. (2009) and Gencoglu and Turkmen (2006), the concentrations of isobutyrate, isovalerate, and valerate were similar among the diets, which might be due to the similar degradation of protein because branched-chain VFA are derived primarily from dietary proteins (Berthiaume et al., 2010).

In our study, treatments had no effect on the total tract DM and OM digestibilities, but fiber digestibility can be increased when cows are fed a RS diet. However, increasing levels of concentrate in the diet of ruminants usually results in increased total DM and OM digestibilities (Ramos et al., 2009). However, fiber digestibility can be reduced, especially when cows are fed grain-based concentrate (Carro et al., 2000). Ruminal digestibility of OM, NDF, and ADF was decreased by increasing the proportion of concentrate, but no differences between forages were detected (Ramos et al., 2009). Forage:concentrate ratio and concentrate mixtures are similar among these four diets, which may have contributed to our previously reported results. In addition, our digestibility results reflect those in Eastridge (Eastridge et al., 2009), where total tract OM digestibility was similar for a diet fed to lactating cows with $357 \mathrm{~g} / \mathrm{kg}$ corn silage plus $117 \mathrm{~g} / \mathrm{kg} \mathrm{AH}, 70.2 \mathrm{~g} / \mathrm{kg}$ grass hay, or $52.2 \mathrm{~g} / \mathrm{kg} \mathrm{RS}$, respectively; the ADF and NDF digestibilities were higher for cows fed RS compared to those fed $\mathrm{AH}$. The slow rate of degradation may have increased its residence time in the rumen compared to the AH and grass hay, which may have contributed to the higher total tract digestibility of fiber for RS diet.

Maximal MCP yield depends on the synchronous availability of $\mathrm{N}$ and energy within the rumen (Moscardini et al., 1998), therefore, the reduced flows of MCP for RS diet compared with other treatments suggested a decreased potential to provide adequate amounts of energy for the synthesis of MCP, though the NFC contents were similar among the four diets. In our study, the forage:concentrate ratio and $\mathrm{OM}$ digestibility were not affected by the treatments, and they are the predominant factors contributing to the MCP yield (Khorasani et al., 2001). In addition, the concentrations of $\mathrm{NH}_{3}-\mathrm{N}$, urine output, and BUN tended to increase with RS diet compared with $\mathrm{AH}$ diet. These findings are consistent with Zhu et al. (2013) who reported that the reduced urinary $\mathrm{N}$ and BUN in the cows fed $\mathrm{AH}$ indicated reduced $\mathrm{N}$ losses and improved ammonia utilization, which resulted in higher MCP yield for $\mathrm{AH}$ diet than those fed grass hay or straw diets. However, the MCP yield in RS diet $(1,699 \mathrm{~g} / \mathrm{d})$ was sufficient for latcation dairy cows as the passage of MCP to the small intestine averaged 1,656 g/d (Clark et al., 1992), and the value was also agreement with Zhu et al. (2013) who reported the MCP yields ranged from 1,601 to 1,876 $\mathrm{g} / \mathrm{d}$ in early lactating dairy cows. 


\section{CONCLUSIONS}

This study demonstrates that $\mathrm{AH}, \mathrm{OH}, \mathrm{LC}$, and RS can be added on the corn silage based diets for the midlactation dairy cows, and forage sources have no effect on the DMI, rumen fermentation characteristics, and milk performance. Although MCP production was lower for cows fed a diet containing low-quality forage such as RS than for those fed $\mathrm{AH}, \mathrm{OH}$, or LC diets, there was no significant difference in the yield of milk protein. Feeding these diets with equivalent concentrations of FNDF from $\mathrm{AH}, \mathrm{OH}, \mathrm{LC}$, and RS, while maintaining similar concentrations of NFC content, would result in similar ruminal fermentation and animal performance by dairy cows. Consequently, we can consider choosing different forages as fiber sources if the nutrient compositions are well balanced in the diets.

\section{ACKNOWLEDGMENTS}

This work was supported by colleges and universities in Jiangsu Province plans to graduate research and innovation (CXLX12_0933) and national "Twelfth Five-Year" Science and Technology supporting plan (2011BAD17B03).

\section{REFERENCES}

Adin, G., R. Solomon, M. Nikbachat, A. Zenou, E. Yosef, A. Brosh, A. Shabtay, S. J. Mabjeesh, I. Halachmi, and J. Miron. 2009. Effect of feeding cows in early lactation with diets differing in roughage-neutral detergent fiber content on intake behavior, rumination, and milk production. J. Dairy Sci. 92:3364-3373.

AOAC. 1990. Official Methods of Analysis. 15th edn. Association of Offical Analytical Chemists, Arlington, VA, USA.

Berthiaume, R., C. Benchaar, A. V. Chaves, G. F. Tremblay, Y. Castonguay, A. Bertrand, G. Bélanger, R. Michaud, C. Lafrenière, T. McAllister, and A. F. Brito. 2010. Effects of nonstructural carbohydrate concentration in alfalfa on fermentation and microbial protein synthesis in continuous culture. J. Dairy Sci. 93:693-700.

Cantalapiedra-Hijar, G., D. R. Yáñez-Ruiz, A. I. Martín-García, and E. Molina-Alcaide. 2009. Effects of forage:concentrate ratio and forage type on apparent digestibility, ruminal fermentation, and microbial growth in goats. J. Anim. Sci. 87:622-631.

Carro, M. D., C. Valdés, M. J. Ranilla and J. S. González. 2000. Effect of forage to concentrate ratio in the diet on ruminal fermentation and digesta flow kinetics in sheep offered food at a fixed and restricted level of intake. Anim. Sci. 70:127-134.

Chaney, A. L. and E. P. Marbach. 1962. Modified reagents for determination of urea and ammonia. Clin. Chem. 8:130-132.

Chen, X. B. and M. Gomes. 1995. Estimation of Microbial Protein Supply to Sheep and Cattle Based on Urinary Excretion of Purine Derivatives - An Overview of the Technical Details. International Feed Resources Unit, Rowett Research Institute, Bucksburn, Aberdeen, AB2 9SB, UK.

Clark, J. H., T. H. Klusmeyer, and M. R. Cameron. 1992.
Microbial protein synthesis and flows of nitrogen fractions to the duodenum of dairy cows. J. Dairy Sci. 75:2304-2323.

Eastridge, M. L., P. B. Bucci, and C. V. D. M. Ribeiro. 2009. Feeding equivalent concentrations of forage neutral detergent fiber from alfalfa hay, grass hay, wheat straw, and whole cottonseed in corn silage based diets to lactating cows. Anim. Feed Sci. Technol. 150:86-94.

Gencoglu, H. and I. I. Turkmen. 2006. Effects of forage source on chewing and rumen fermentation in lactating dairy cows. Revue Méd. Vét. 157:463-470.

Gencoglu, H., I. I. Turkmen, G. Deniz, and H. Biricik. 2007. The effect of partial replacement of corn silage on rumen degradability, milk production and composition in lactating primiparous dairy cows. Ital. J. Anim. Sci. 6:71-80.

Guo, T. S., D. M. Sánchez, and P. Y. Guo. 2002. Animal Production Based on Crop Residues - Chinese Experiences. FAO, Rome, Italy. pp. 6-8.

Haddad, S. G. and R. J. Grant. 2000. Influence of nonfiber carbohydrate concentration on forage fiber digestion in vitro. Anim. Feed Sci. Technol. 86:107-115.

Holt, M. S., J.-S. Eun, C. R. Thacker, A. J. Young, X. Dai, and K. E. Nestor Jr. 2013. Effects of feeding brown midrib corn silage with a high dietary concentration of alfalfa hay on lactational performance of Holstein dairy cows for the first 180 days of lactation. J. Dairy Sci. 96:515-523.

Kendall, C., C. Leonardi, P. C. Hoffman, and D. K. Combs. 2009. Intake and milk production of cows fed diets that differed in dietary neutral detergent fiber and neutral detergent fiber digestibility. J. Dairy Sci. 92:313-323.

Khorasani, G. R., E. K. Okine, and J. J. Kennelly. 2001. Effects of forage source and amount of concentrate on rumen and intestinal digestion of nutrients in late-lactation cows. J. Dairy Sci. 84:1156-1165.

Kononoff, P. J. and A. J. Heinrichs. 2003. The Effect of corn silage particle size and cottonseed hulls on cows in early lactation. J. Dairy Sci. 86:2438-2451.

Moscardini, S., T. C. Wright, P. H. Luimes, B. W. McBride, and P. Susmel. 1998. Effects of rumen-undegradable protein and feed intake on purine derivative and urea nitrogen: Comparison with predictions from the cornell net carbohydrate and protein system. J. Dairy Sci. 81:2421-2429.

Owens, D., M. McGee, T. Boland, and P. O'Kiely. 2009. Rumen fermentation, microbial protein synthesis, and nutrient flow to the omasum in cattle offered corn silage, grass silage, or whole-crop wheat. J. Anim. Sci. 87:658-668.

Ramos, S., M. L. Tejido, M. E. Martínez, M. J. Ranilla, and M. D. Carro. 2009. Microbial protein synthesis, ruminal digestion, microbial populations, and nitrogen balance in sheep fed diets varying in forage-to-concentrate ratio and type of forage. J. Anim. Sci. 87:2924-2934.

Ranathunga, S. D., K. F. Kalscheur, A. R. Hippen, and D. J. Schingoethe. 2010. Replacement of starch from corn with nonforage fiber from distillers grains and soyhulls in diets of lactating dairy cows. J. Dairy Sci. 93:1086-1097.

Rode, L. M., D. C. Weakley and L. D. Satter. 1985. Effect of forage amount and particle size in diets of lactating dairy cows on site of digestion and microbial protein synthesis. Can. J. Anim. Sci. 65:101-111.

Samuel, M., S. Sagathewan, J. Thomas, and G. Mathen. 1997. An 
HPLC method for estimation of volatile fatty acids of ruminal fluid. Indian J. Anim. Sci. 69:805-807.

Su, Y., G. Zhao, Z. Wei, C. Yan, and S. Liu. 2012. Mutation of cellulose synthase gene improves the nutritive value of rice straw. Asian Australas. J. Anim. Sci. 25:800-805.

Valadares, R. F. D., G. A. Broderick, S. C. Valadares Filho, and A H. M. K. Clayton. 1999. Effect of replacing alfalfa silage with high moisture corn on ruminal protein synthesis estimated from excretion of total purine derivatives. J. Dairy Sci. 82: 2686-2696.

Van Soest, P. J., J. B. Robertson, and B. A. Lewis. 1991. Methods for dietary fiber, neutral detergent fiber, and nonstarch polysaccharides in relation to animal nutrition. J. Dairy Sci. 74:3583-3597.

Vanhatalo, A., K. Kuoppala, S. Ahvenjärvi, and M. Rinne. 2009. Effects of feeding grass or red clover silage cut at two maturity stages in dairy cows. 1. Nitrogen metabolism and supply of amino acids. J. Dairy Sci. 92:5620-5633.
Wang, J. Q. 2011. Five key indicators leading the direction of China dairy industry. China Anim. Husbandry Vet. Med. 38:59.

Yan, R., S. Chen, X. Zhang, J. Han, Y. Zhang and D. Undersander. 2011. Short communication: Effects of replacing part of corn silage and alfalfa hay with Leymus chinensis hay on milk production and composition. J. Dairy Sci. 94:3605-3608.

Yang, H. J., Q. Yue, Y. C. Cao, D. F. Zhang, and J. Q. Wang. 2009. Effects of crude feruloyl and acetyl esterase solutions of Neocallimastix sp. YQ1 and Anaeromyces sp. YQ3 isolated from Holstein steers on hydrolysis of Chinese wildrye grass hay, wheat bran, maize bran, wheat straw and corn stalks. Anim. Feed Sci. Technol. 154:218-227.

Zhu, W., Y. Fu, B. Wang, C. Wang, J. A. Ye, Y. M. Wu, and J.-X. Liu. 2013. Effects of dietary forage sources on rumen microbial protein synthesis and milk performance in early lactating dairy cows. J. Dairy Sci. 96:1727-1734. 